\title{
Genic Analysis in Rice. IV. Genes for Purple Pericarp and Other Characters
}

\author{
Sung-Ching Hsien and Te-Mei Chang \\ (Taiwan Agricultural Research Institute, Taipei)
}

Two types pericarp coloration, red and purple, are found in rice, Oryza sativa L. The red pericarp was considered by NAGAI (1921) as well as by NAGAo (1951) to be due to protocyan pigment, but later was found to be due to catechin, catechol tannin and phlobaphene, produced by the interaction of $R c$ and $R d$ (NAGAO, TAKAHAsHI and Miyamoto 1957). The purple pericarp was found by Ramiah et al. (1931) to be controlled by a gene $P$ which expresses the character if other pigmentation genes $A$ and $N$ are present. On this basis, NAGAO (1951) considered that this character might be due to the complementary effect of anthocyanic pigmentation genes $C$ and $A$, and another gene $P p$ which spreads pigment into the pericarp. Later, NAGAo and TAKAHASHI (1962) found that a gene $P l$ is concerned with the coloration of the leaf blade, leaf sheath, auricle, ligule, node and internode, and further with that of the pericarp exposed to direct sunlight.

The present experiment was conducted with the view of reexamining NAGAo and TAKAHASHI's conclusions and finding linkage relationships between the genes controlling purple pericarp and other characters.

Table 1. List of strains used as cross parents

\begin{tabular}{|c|c|c|c|}
\hline Strain No. & Genetic characters & $\begin{array}{l}\text { Putative genic } \\
\text { constitution }\end{array}$ & Note \\
\hline 7041 & Purple apiculus, long empty glume & $C^{B} A \ln g$ & JoDON's marker \\
\hline 7101 & Purple apiculus, stigma, hull and leaf blade & $P l H p(R p)$ & $\prime \prime$ \\
\hline 7102 & Purple apiculus, stigma, leaf blade and hull & $P l H p(R p) P p P b$ & " \\
\hline 7107 & Purple apiculus, stigma and hull & $H p(R p)$ & $\prime \prime$ \\
\hline 7227 & $\begin{array}{l}\text { Apiculus ripening tawny, glutinous endo- } \\
\text { sperm, grabrous hull }\end{array}$ & $a p w x l k p p p b$ & $\prime \prime$ \\
\hline 7252 & $\begin{array}{l}\text { Apiculus, stigma, pericarp and leaf purple, } \\
\text { minute grain }\end{array}$ & $P p P b M i P l$ & $\prime \prime$ \\
\hline A-5 & Red apiculus, ripening purple hull & $C^{B r} A R p$ & $\begin{array}{l}\text { NAGAO's marker } \\
\text { (Akamuro) }\end{array}$ \\
\hline D-8-5 & Apiculus colorless, dwarf (50 cm in height) & $c a d$ lro $p p p b$ & $\begin{array}{l}\text { Mutant from Chianan No. } 8 \\
\text { (Taiwan) }\end{array}$ \\
\hline D-8-9 & Apiculus colorless, dwarf (55 $\mathrm{cm}$ in height) & $c a d p p p b$ & "1 \\
\hline M-8-7 & $\begin{array}{l}\text { Apiculus colorless, dwarf }(50 \mathrm{~cm} \text { in height) } \\
\text { grassy leaf }\end{array}$ & $c a d p p p b$ & $\prime \prime$ \\
\hline La-8-9 & Apiculus colorless, lazy & $c a l a p p p b$ & $\prime \prime$ \\
\hline D-155-5 & $\begin{array}{l}\text { Apiculus brown, grassy dwarf }(30 \mathrm{~cm} \text { in } \\
\text { height), much tiller number }\end{array}$ & $C a d p p p b$ & $\begin{array}{l}\text { Mutant from Taichung } \\
\text { No. } 155 \text { (Taiwan) }\end{array}$ \\
\hline$P-167$ & Brown apiculus, liguleless & C a lg & Pai-kan-tao (Taiwan) \\
\hline $\mathrm{J}-308$ & Red apiculus, liguleless & $C^{B r} A l g$ & Muzetsuto (Japan) \\
\hline M-514 & Purple apiculus, purple pericarp & $C^{B} A P p P b$ & Hun-nou(China mainland) \\
\hline
\end{tabular}

Received Nov. 28, 1963 


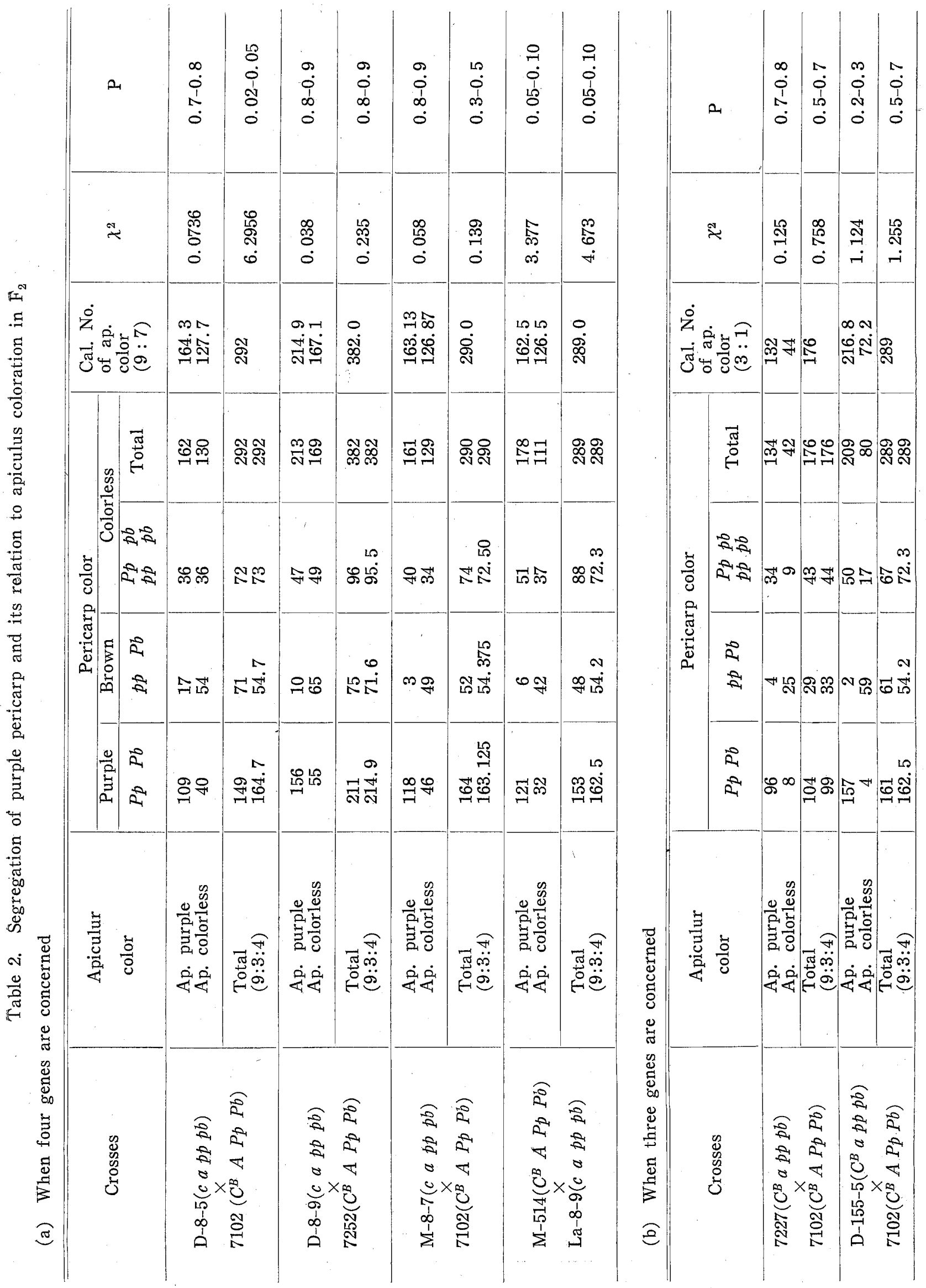




\section{Materials and Methods}

The strains used for this experiment are listed in Table 1. Among them, six are gene markers sent from Dr. N. E. Jodon, and one was furnished by Dr. S. NAGAO; the writers are greatly obliged to those two scholars. The rest are strains selected from Taiwanese, Japanese and Chinese native varieties, and radiation-induced mutants of Ponlai (Japonica type) varieties. These strains were raised in the experimental field of Taiwan Agricultural Research Institute, Taipei, and records were taken regarding pigmentations at the apiculus, leaf blade, pericarp, hull, stigma, internode and ligule. The gene symbols recommended by International Rice Commission of FAO (1959) were used. The gene symbol $A-a$, identical to $S p-s p$ formerly used by Dr. S. NAGAo, is also adopted in this paper.

\section{Presentation of Data}

\section{Inheritance of purple pigmentation of pericarp}

Strains 7102, 7252 and M-514 have purple pericarps; the pigment is spread over the surface of the grains. For examining the distribution of pigment in the grain, sections cut at 20 micra were observed. The pigment was found to be limited to the pericarp.

$\mathrm{F}_{2}$ segregation ratios for purple pericarp and their relation to apiculus coloration are shown in Table 2. As the data in the table show, crosses between plants with purple and colorless pericarps gave a 9 purple : 3 brown : 4 colorless ratio. This is in accord with the results obtained by Ramiah et al. (1931). We may assume from this ratio that the purple pericarp is due to a set of complementary genes, $P p$ and $P b$, and that $P b$ alone brings about brown pericarp. Under this assumption, strains $D-8-5$, D-8-9, M-8-7, 7227 and D-155-5 must have the resessive genes $p p$ and $p b$, while strains 7102, 7252 and $\mathrm{M}-514$ have $P p$ and $P b$.

In these crosses, the segregation for apiculus coloration was due to $C^{B}: c$ and $A: a$ (giving $9: 7$ ratios), or to $A: a$ (3:1 ratios). In both cases, it was found that apiculus-purple plants mostly had purple pericarps while apiculus-colorless plants plants mostly had brown pericarps. This indicates that the gene $P p$ might be linked with the apiculus-pigmentation gene $A$.

Dividing the $F_{2}$ data into two groups, one (a) showing $3: 1$ ratio and the other (b) showing $9: 7$ ratio for apiculus coloration, as shown in Table 2, a chi-square test of heterogeneity (c. f. SNEDECOR 1950) was made regarding segregation ratios found in various crosses of each group. The results proved that all the observed segregations in each group could be

Table 3. Frequencies of phenotypic classes with four genes concerned

\begin{tabular}{l|l|c|c|r}
\hline Apiculus & Pericarp & Frequency & Obs. no. & Exp. no. \\
\hline Purple & Purple & $\frac{9}{64}\left(3-2 p+p^{2}\right)$ & 504 & 498.5 \\
$\prime \prime$ & Brown & $\frac{9}{64}\left(2 p-p^{2}\right)$ & 36 & 30.1 \\
$\prime \prime$ & Colorless & $\frac{9}{64}$ & 174 & 176.2 \\
Colorless & Purple & $\frac{9}{64}\left(1+2 p-p^{2}\right)$ & 173 & 206.3 \\
" & Brown & $\frac{3}{64}\left(4-6 p+3 p^{2}\right)$ & 210 & 204.9 \\
" & Colorless & $\frac{7}{64}$ & 156 & 137.0 \\
\hline \multicolumn{2}{|r}{$p=8.39 \%$} & $\chi^{2}=9.72$ & $P>0.05$
\end{tabular}


considered as homogeneous. Then the recombination fraction between $A$ and $P p$ was computed from the pooled data as follows:

When a 9: 7 ratio is found for apiculus coloration, the frequencies of $F_{2}$ plants falling under six phenotypic classes will be formulated as given in Table 3. By using the maximumlikelihood technique, the recombination value, $p$, was estimated to be $8.93 \pm 0.46 \%$, and the observed numbers fitted well the expected ones. In the same manner, in crosses showing $3: 1$ ratios for apiculus coloration the frequencies of phenotypic classes were computed as given in Table 4 . The recombination value was found to be $5.12 \pm 1.21 \%$, also giving a good

Table 4. Frequencies of phenotypic classes with three genes concerned

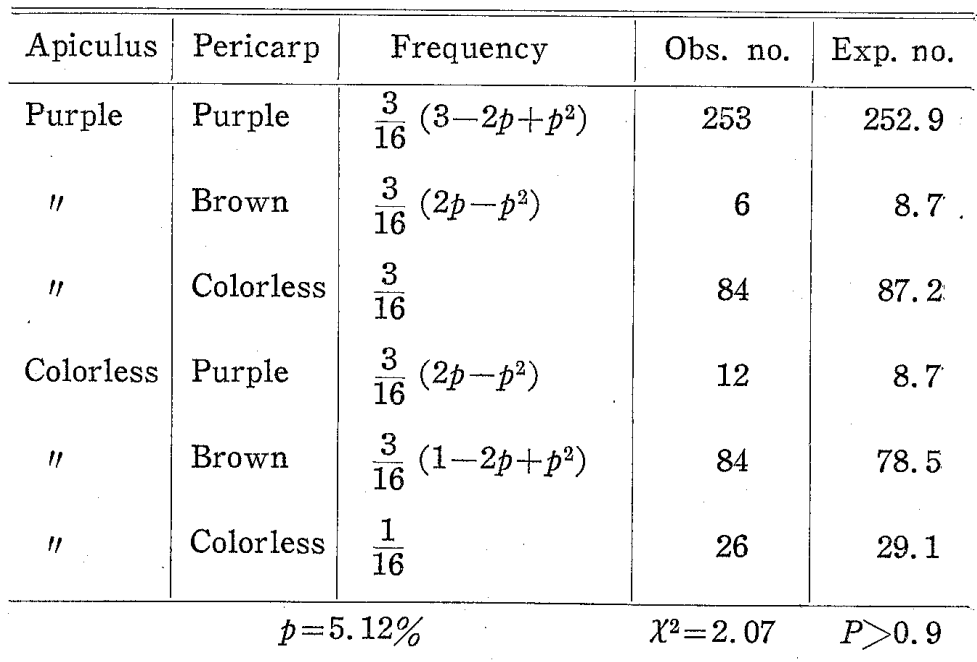
fitness of observed to expected numbers.

\section{Inheritance of leaf-blade pigmentation}

The leaf blade of strains 7102 and 7252 is purple. These strains might have a gene named $P l$ by NAGAO (1951), which produces purple pigment in the leaf blade in cooperation with the apiculus-pigmentation genes $C$ and $A$; their genotype may be assumed to be $C^{B} A P l$. When they were crossed with colorless strains $\mathrm{D}-8-5$ etc.

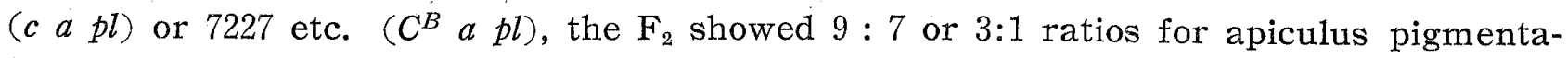
tion, and $27: 37$ or $9: 7$ ratios for leaf-blade pigmentation, while the plants with purple leaf blade always showed purple apiculus, as shown in Table 5. This is in accord with the conclusion of NAGAO and TAKAHASHI (1962).

The relation between leaf blade and pericarp colorations was further examined. As

\begin{tabular}{|c|c|c|c|}
\hline Genotype & Apiculus & Leaf blade & Pericarp \\
\hline$C A-P p P b=P l$ & Purple & Purple & Purple \\
\hline$C A-P p p b=p l$ & Purple & Colorless & Colorless \\
\hline$C A-p p P b=P l$ & Purple & Purple & Brown \\
\hline$C A-p p \quad p b=p l$ & Purple & Colorless & Colorless \\
\hline 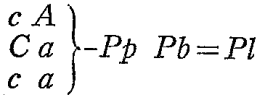 & Colorless & Colorless & Purple \\
\hline 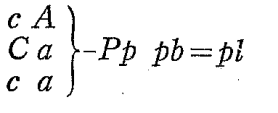 & Colorless & Colorless & Colorless \\
\hline $\left.\begin{array}{ll}c & A \\
C & a \\
c & a\end{array}\right\}-p p \quad P b=P l$ & Colorless & Colorless & Brown \\
\hline $\left.\begin{array}{ll}c & A \\
C & a \\
c & a\end{array}\right\}-p p \quad p b=p l$ & Colorless & Colorless & Colorless \\
\hline
\end{tabular}
shown in Table 5, no plants with. purple leaf blade and colorless. pericarp appeared. This suggests that $P l$ and $P b$ are very closely linked, or that the pigmentation of pericarp and that of leaf blade are due to pleiotropic effects of the samegene. Summarizing the above statements, the phenotypes of various gene combinations may be expected. to be as given on the left: $(=$ shows. linkage.)

The recombination fraction be- 


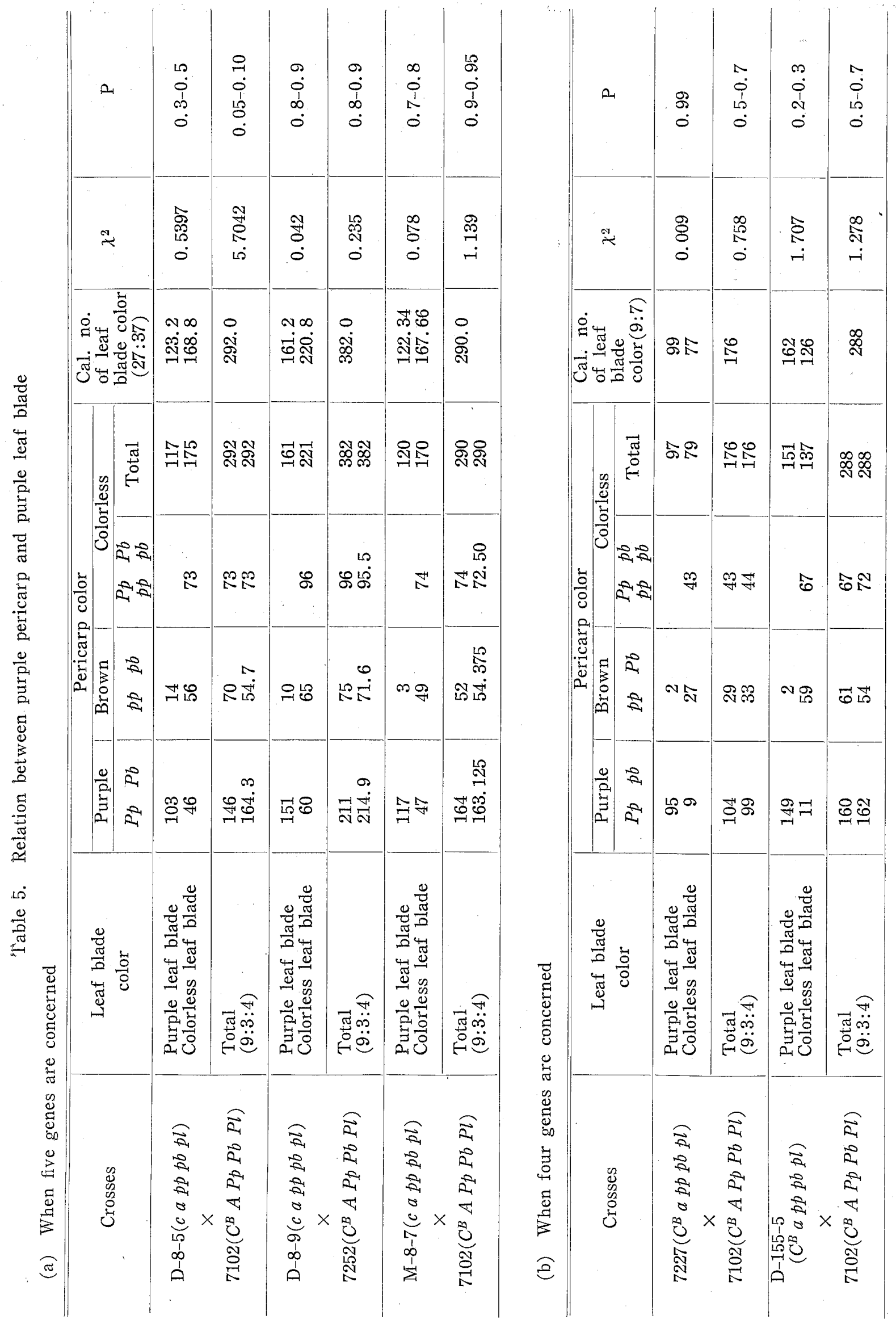


tween $A$ and $P p$ was estimated again from the data of Table 5 ; it was found to be 9.48 $\pm 2.23 \%$ (from crosses in which five genes are concerned) or $6.78 \pm 0.78 \%$ (four genes).

It may then be concluded that the purple coloration of the pericarp is due to two genes $P p$ and $P b$, and that $P p$ is linked with $A$, while $P b$ is synonymous with $P l$, which produces the purple pigmentation of leaf blade when $C$ and $A$ are present.

\section{Colorations of hulls}

The hulls of 7102 and 7252 are blackish. The gene determining this character was called $H p$ by Jodon $(1948,1955,1956)$ and $R p(=P r)$ by NAGAO (1951). It was found that $R p$ was linked with $P l(=P b)$ as shown in Table 6 . The average recombination fraction was estimated to be $20.26 \pm 1.73 \%$.

\section{Ligulelessness and other characters}

Strains P-167 and J-308 have no ligules. This character showed a monogenic segregation. The gene symbol $l g$ was given by Jodon (1948). The gene $l g$ was found to be linked with $R p$. The average recombination value was estimated to be $29.24 \pm 2.34 \%$ as shown in Table 7. This value is in close agreement with the value found by NAGAO and TAKAHASHI (1952), $28.2 \%$.

Induced mutant strains $D-8-5, D-8-9$ and $M-8-7$ are dwarfs, the height at maturity being about $50 \mathrm{~cm}$; the strain D-155-5 is a "grassy" dwarf with profuse tillers, the height being about $30 \mathrm{~cm}$. These dwarf strains were found to carry a recessive gene, as reported by the writer before (HsIeH 1962). These dwarf genes showed no linkage relations with $P p$ and $P b$.

\section{Discussion}

The main interest in the present study was to analyse the system of genes controlling the pigmentation of the pericarp and other organs and to find out linkage relationships between those and other genes.

It is known that the genes controlling apiculus pigmentation, $C$ and $A$, may be regarded as basic factors for the pigmentation of other organs. For instance, regarding stigma pigmentation, the writer (1960) formerly reported that plants with colored stigmas always had colored apiculus, but the coloration of the apiculus is not always correlated with that of stigmas. For leaf-blade coloration, the gene $P l$ seems to cause the distribution of pigment produced by $C$ and $A(=S p)$ in the leaf blade (NAGao 1951).

It was found that in certain cases a gene controlling pigmentation of a particular organ becomes effective when $C$ and $A$ are present, while in other cases a gene produces pigment without the cooperation of $C$ and $A$. Different systems of coloration genes seem to make up a comlex. It is interesting to find that two genes express the purple coloration of pericarp in apiculus-colorless plants, but one of them simultaneously determines the leaf-blade coloration with the aid of the apiculus-pigmentation genes. This differs from NAGAO and TAKAHASH's (1962) conclusion that the gene $P l$ is responsible for the distribution of anthocyanin produced by $C$ and $A$ into the leaf, internode, node and pericarp.

Regarding the linkage relationships of the purple pericarp gene with other genes, 


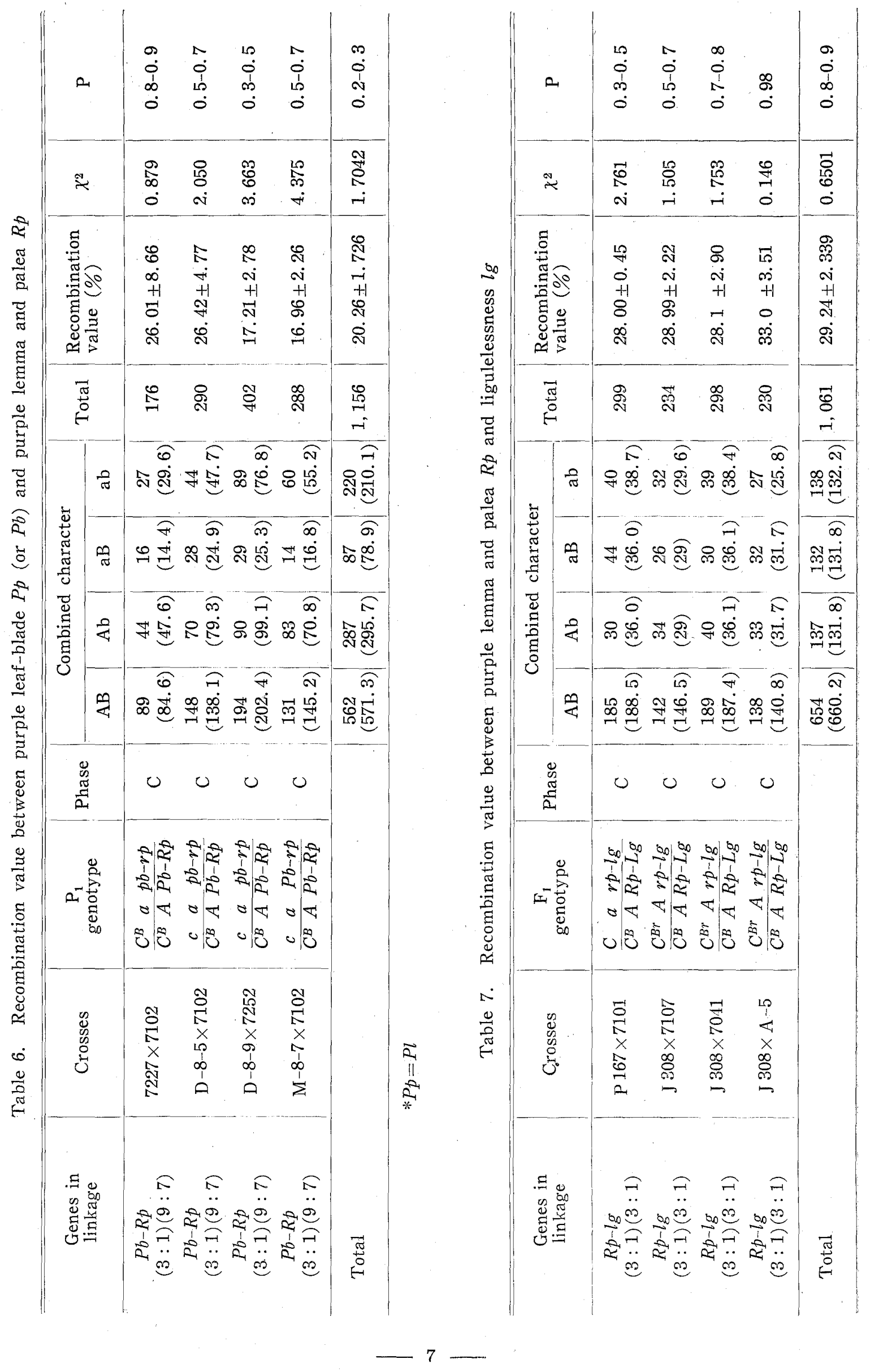


JoDon (1948) found that the purple pericarp gene Prp was linked with the purple junctura $(J p b)$, purple glume $(G p b)$, purple hull $(H p b)$ and purple internode $(N t p)$ genes, all belonging to his linkage group III. Later, this group was revised as group II (JodON 1955). This may correspond to NAGAO and TAKAHASHI's (1959) $P l$ group or group II, in which seven genes, $P l, d_{2}, d_{3}, l g, P h, R p(=P r)$ and $P$ (formerly symboled as $A$ ) are involved.

In the present study, it was found that $P p$ was linked with $A$ which belongs to NAGAO's group III. Further linkages were found between $P b(=P l)$ and $R p$, and between $l g$ and $R p$, which belong to NAGAo's group II. The dwarf gene $d_{9}$ was formerly found to be linked with $\lg$ (HsIEH 1962). Further, the phenol reaction gene $P h$ was found to be linked with the stigma coloration gene $P_{S_{1}}$ (HsiEH unpublished). All these genes seem to belong to the same group. Their order has to be studied in the future.

\section{Summary}

In order to analyse the genic system for purple coloration of the pericarp and its linkage relations, the $F_{2}$ ratios for the purple coloration of pericarp were investigated with particular attention to its linkage relations to the anthocyanic pigmentation of various other organs. When strains with colored and colorless pericarps are crossed, 9 purple : 3 brown : 4 colorless ratios were found in the $F_{2}$. It was assumed that two genes $P p$ and $P b$ are concerned with the purple coloration of the pericarp; $P p$ is epistatic to $P b$, and $P p$ was found to be closely linked with $A$, one of apiculus-coloration genes, with a recombination fraction of $5.1-9.4 \%$. They belong to the linkage group III of NAGAO and TAKAHASHI.

The purple coloration of leaf blade is controlled by a modifier $P l$ which distributes anthocyanic pigment produced by $C^{B}$ and $A$. It is completely linked with, or synonimous with $P b$. Linkage relations were found further between the purple pericarp gene $P b(=P l)$, the purple lemma and palea gene $R p$, and the ligulelessness gene $l g$. All of these genes appeared to belong to group II of NAGAO and TAKAHASHI.

The writers wish to express their thanks to Dr. M. E. TAKAHAshi, Hokkaido University, and Dr. H. I. OKA, National Institute of Genetics, for their kind review of the manuscript.

\section{Literature Cited}

HsIEH, S. C. 1960. Genic analysis in rice, I. Coloration genes and inheritance of other characters in rice. Bot. Bull Acad. Sinica 1(2): 117-132.

1962. Genic analysis in rice, III. Inheritance of mutations induced by irradiations in rice. Bot. Bull. Acad. Sinica 3(2): 151-162.

JODON, N. E. 1948. Summary of rice linkage data. Mimeographed by Bureau of Plant Industry, Soils and Agr. Eng., Division of Cereal Crops and Diseases, USDA: 1-33.

1955. Present status of rice genetics. Jour. Agr. Assoc. China, New Series 10: 5-21.
1956. Revision of figure 3 to 6 , "Present status of rice genetics". Jour. Agr. Assoc. China, New Series 14: 69 $<73$.

NAGAI, I. 1921. A genetico-physiological study on the formation of anthocyanin and brown pigments in plants. Jour. Col. Agr. Imp. Univ. Tokyo 8: 1-92.

NAGAO, S. 1951. Genic analysis and linkage relationship of characters in rice. Advances in Genetics, 4 : 181-212.

_ and M. TAKAHASHI 1952. Genetical studies on rice plant, XIV. The order and distance 
of some genes belong to $P l$ - linkage group in rice. Jap. Jour. Breed. 1(4): 237-240. and 1956. Genetical studies on rice plants, XIX. The third gene for apiculus coloration. Jap. Jour. Bot. 15(2) : 141-151. and 1959. Linkage groups in rice.

Report of Plant Breed. Inst., Fac. Agr., Hokkaido Univ., Sapporo, Japan. - and T. Miyamoto 1957. Genetical studies on rice plants, XXI. Biochemical studies on red rice pigmentation. Jap. Jour. Genet. 32(4) : 124-128.

NAGAO, S. and M. TAKAHASHI 1962. Genetical studies on rice plants, XXVI. Mode of inheritance and causal genes for one type of anthocyanin color character in foreign rice varieties. Jour. Fac. Agr., Hokkoido Univ. 52(1) : 20-50.

RAMIAH, K., S. JABITHARA and S. D. MUdALIAR 1931. The inheritance of characters in rice, Dept. Agr. Ind. Mem. Bot. 18 : 159-209.

\section{稲の遺伝子分析 第 4 報}

\section{果皮の紫色着色に関与する遺伝子}

謝順景・張徳 梅

（台湾省台北市 台湾省農業試験所）

稲の果皮部にみられる紫色系着色につき，その関与遺 伝子を他部位, 着色の遺伝子との関連の下にしらべてみ た。得られた知見の大要は次の如くである。

（1）果皮色には $P b$ 及び $P p$ の 2 遺伝子が関与し, 両 者共存してはじめて紫色となる。但し $P b$ は単独でる果 皮学褐色ならしめる作用学问つ。

（2） PpはA（稃先の花青素着色遗伝子：Activator） と $5.1 \%$ 乃至 $9.4 \%$ の組換洒で連鎖し,これらは長尾・ 高橋の第亚連鎖群に所属する。

（3）葉身の紫色着色は $A$ と C (稃先の花青素着色遺 伝子: Chromogen) の存在の下に $P l$ (葉身色分布遺伝 子）が加わつて発現されるものとみなしてよいが，本実 験では $P b$ が常に $P l$ と相件つて行動した。このことは $P b$ が $P l$ と極めて強度に連鎖するか，あるいは香た， $P b$ なるものは $P l$ の多発作用に外ならないかの何れかで央
ることを意味する。

（4）既に知られた如く, $P l$ や $R p$ (頴色分布賛伝子。 $P r$ とも記す）恃長尾・高橋の第正連鎖群に所属するが, 上記の $P b$ は $R p$ との間に組換価 $20.3 \%$ 連鎖を示した。

(5) $\lg$ (無葉舌) について連鎖分析を行ったところ, $R p$ との間に $29.2 \%$ なる組換価を得た。これは $\lg$ が 第群に所属するとの従来の報告に一つの支持資料を加 えたことになる。

（6） $C \cdot A$ 雨遺伝子の存在が稻体各部の花青素着色 の発現に重要なる前提条件であることは事実としても， 絶対不可欠か否かについてはな和多くの実験の集積が望 ましい。この点に関し， $P b$ 及び $P p$ の今後の詳細なる 分析は, 若しそれらが花青素系着色であるならば, 興味 ある資料党提供するものと考它られる。 